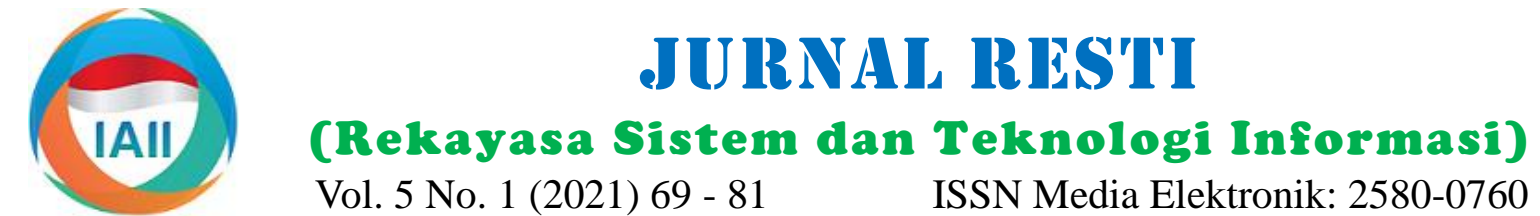

\section{Analisis Kesiapan Masyarakat Pada Penerapan Smart City di Sosial Media Menggunakan SNA}

\author{
M. Khairul Anam ${ }^{1}$, Tri Putri Lestari ${ }^{2}$, Latifah $^{3}$, Muhammad Bambang Firdaus ${ }^{4}$, Sofiansyah Fadli ${ }^{5}$ \\ 1,2Jurusan Teknik Informatika, STMIK Amik Riau \\ ${ }^{3}$ Jurusan Teknik Informatika, Fakultas Teknik dan Ilmu Komputer, Universitas Teknokrat Indonesia \\ ${ }^{4}$ Program Studi Informatika, Fakultas Teknik, Universitas Mulawarman \\ ${ }^{5}$ Jurusan Teknik Informatika, STMIK Lombok \\ ${ }^{1}$ khairulanam@sar.ac.id*, ${ }^{2}$ triputrilestarii@gmail.com, ${ }^{3}$ lathifah@ teknokrat.ac.id, ${ }^{4}$ bambangf@ fkti.unmul.ac.id, \\ ${ }^{5}$ sofiansyah@stmiklombok.ac.id
}

\begin{abstract}
Smart People, which means smart city residents or people, not only refers to one's education but also the quality of social interactions that are formed. This Social Network Analysis (SNA) emphasizes the relationship between actors / users rather than the attributes of these actors. This analysis aims to see whether the people of Pekanbaru are ready to face changes to a Smart City. Pekanbaru is a civil city that will build a Smart City, with a concept that adopts 6 pillars, one of which is Smart People. There are 720,000 Twitter users in Pekanbaru City, while the people who actively interact are only 227 users or around $0.031 \%$. Meanwhile, a city that can be said to be ready should be around 60-80\% of active users who provide opinions or comments to the government of Pekanbaru City. From this research, it can be concluded that the people of Pekanbaru City are not ready to face Smart City Madani as seen from the interaction of the community on social media Twitter.
\end{abstract}

Keywords: Smart city, social Network Analysis, community, Twitter, Pekanbaru

Abstrak

Smart People yang berarti penduduk atau masyarakat Kota yang cerdas, tidak hanya mengacu pada edukasi seseorang tapi juga kualitas interaksi sosial yang terbentuk. Social Network Analysis (SNA) ini lebih menekankan pada hubungan antar aktor/user dari pada atribut actor tersebut. Analisa ini bertujuan untuk melihat apakah masyarakat pekanbaru siap dalam menghadapi perubahan menuju Smart City.Pekanbaru merupakan Kota madani yang akan membangun Smart City, dengan konsep yang diusung mengadopsi 6 pilar, salah satunya adalah Smart People. Terdapat 720.000 user pengguna twitter di Kota Pekanbaru sedangkan masyarakat yang aktif berinteraksi hanya terdapat 227 user atau sekitar $0.031 \%$. Sedangkan Kota yang bisa dikatakan siap harus sekitar 60-80\% dari user aktif yang memberikan opini atau komentar pada pemerintah Kota Pekanbaru. Dari penelitian ini di dapat bahwa masyarakat Kota Pekanbaru Belum Siap dalam menghadapai Smart City Madani dilihat dari interaksi masyarakat dimedia sosial Twitter.

Kata kunci: Smart city, social Network Analysis, masyarakat, Twitter, Pekanbaru

\section{Pendahuluan}

Indonesia merupakan negara di Asia Tenggara yang memiliki jumlah penduduknya sebanyak 268.583.016 jiwa [1]. Jumlah pengguna internet di Indonesia hingga kuartal II tahun 2020 naik menjadi 73,7 persen dari Smart City dapat diartikan dengan sederhana adalah kota populasi atau sekitar 196, 7 juta pengguna [2]. pintar atau kota cerdas yang bisa memberikan mutu Penggunaan internet di Indonesia banyak digunakan hidup yang baik dan kedamaian terhadap untuk berbagai hal, salah satunya adalah menggunakan masyarakatnya [4], Untuk menerapkan Smart City salah sosial media. Salah satu sosial media yang sering satu bagian yang terpenting adalah interaksi masyarakat digunakan masyarakat Indonesia adalah Twitter, online (Netizen) terhadap pemerintah. untuk itu pengguna twitter di Indonesia saat ini mencapat pemerintah perlu melihat bagaimana interaksi netizen 
terhadap kota Pekanbaru, sehingga pemerintah bisa command center sebagai wujud layanan untuk melakukan inovasi dan pembangunan dalam menerapkan Smart City yang berfungsi sebagai alat yang mewujudkan Smart City. bisa dihubungi oleh masyarakat Pekanbaru untuk menyampaikan keluhanan terhadap Kota Pekanbaru.

Penerapan program untuk terciptanya smart city sudah banyak dilakukan inovasi yang dilakukan oleh beberapa peneliti, seperti pada penerapan IOT (INTERNET OF THINGS) untuk menunjang penerapan program yang telah di usulkan pada blueprint smart city yang dimiliki kota-kota yang telah menerapkan smart city [5] dan [6]. Kemudian smart city saat ini sudah diterapkan secara cloud [7], untuk mengantisipasi terjadinya kehilangan data akibat bencana alam ataupun yang lainnya yang mengakibatkan server fisik menalami kerusakan. Pada smart society peneliti melakukan inovasi terhadap web dengan menerapkan Knowlwdge management system untuk budidaya hidroponik [8]. Selain inovasi peneliti juga melakukan kajian terhadap program yang menjadi konsep pengembangan smart city yaitu smart parking system [9], smart parking system biasanya terdapat pada kantor-kantor dinas, mall, kementrian, dan lain sebagainya. Untuk itu perlu adanya pembenahan agar smart parking system ini dapat berjalan dengan baik untuk mendukung terciptanya smart city. Kota-kota besar di Indonesia saat ini sudah menerapkan smart city.

Kota-kota seperti, Bandung, Jakarta, Yogyakarta, Surabaya, Medan dan Makasar sudah mulai serius dengan konsep Smart City [10]. Kota-kota yang telah disebutkan di atas telah menerapkan Smart City salah satunya yaitu menyediakan layanan berbasis online bagi masyarakatnya, contohnya Kota Jakarta yang telah menerapkan pelayanan pengaduan masyarakat terhadap pemerintah Kota Jakarta. Penelitian lain mengenai penerapan E-government pada kota-kota yang ada di Indonesia [11], [12], [13], [14] bahwa pelayanan $E$ government yang ada belum terealisasikan dengan baik, dan banyaknya masyarakat yang belum tahu akan layanan yang telah disediakan dan kurang dimanfaatkan oleh masyarakat sehingga layanan tersebut tidak berfungsi dengan baik dan akhirnya diabaikan begitu saja, hal ini menjadi kendala bagi pemerintah dalam menerapkan Smart City di kota-kota tersebut.

Kota Pekanbaru juga menjadi salah satu Kota yang akan ikut serta untuk program Smart City [15]. Hal ini mengharuskan pekanbaru memiliki blueprint Smart City agar program yang diterapkan memiliki dampak tidak hanya pada target keberlanjutan tetapi juga bagi kesejahteraan masyarakat [16]. Saat ini pekanbaru telah membentuk master plan Pekanbaru Smart City melalui Perwako Pekanbaru Nomor 56 tahun 2019 [17]. Dengan adanya Perwako ini pekabaru kedepannya persoalan lingkungan, kesehatan, pendidikan, keagamaan dan sosial budaya, serta ekomoni masyarakat semakin membaik di Kota Pekanbaru [18]. Menurut salah satu Tim Smart City Pekanbaru, menyebutkan bahwa salah satu tindakan pemerintah Pekanbaru dalam menerapkan Dengan adanya Command Center selain untuk memantau kinerja pemerintah Kota Pekanbaru, juga diharapkan bisa memantau apapun yang terjadi di Kota Pekanbaru, dan dapat mengurangi tindak kejahatan yang terjadi di Kota Pekanbaru [19]. Berikut ini adalah program Smart City yang telah diterapkan [17], [19], [20].

Tabel 1. Program Smart City yang telah diterapkan

\begin{tabular}{ll}
\hline Program & Manfaat \\
\hline $\begin{array}{l}\text { Pemberdayaan } \\
\text { Masyarakat }\end{array}$ & $\begin{array}{l}\text { 1. Menciptakan Kerukunan, Keamanan dan } \\
\text { Berbasis }\end{array}$ \\
Kukun Warga & 2. Mewajuan; \\
& Pekanbaru; \\
& 3. Menciptakan Lingkungan Bersih, Sehat dan \\
& Asri; \\
& 4.Peningkatan kesetiakawanan sosial; \\
& 5.Peningkatan kesempatan dan pembukaan \\
& lapangan kerja; \\
& 6. Peningkatan kualitas dan kuantitas sarana, \\
& prasarana dan kelestarian lingkungan.
\end{tabular}

Penerima manfaat: Masyarakat dan pemerintah Manfaat internal dan eksternal mengatasi persoalan dan memenuhi kebutuhan.

Pemberdayaan Pemberdayaan melalui mesjid paripurna juga Masyarakat menekankan pemberdayaan rohani dalam Berbasis pembentukan akhlak dan pemantapan keimanan. Rumah Ibadah Pemerintah memberikan bantuan biaya / Mesjid operasional mesjid dan honor imam mesjid Paripurna (imam besar dan imam rawathib) sebagai stimulan sedangkan kegiatan pemberdayaan meliputi pembinaan generasi muda, pendidikan dan ketrampilan dan usaha-usaha ekonomi mikro berbasis sariah.

Penerima manfaat: Masyarakat dan pemerintah Manfaat internal dan manfaat eksternal yaitu mengatasi persoalan, memenuhi kebutuhan.

Kartu Smart Meningkatnya kepuasan publik karena Madani peningkatan kualitas pelayanan; meningkatnya kesadaran untuk menabung terutama bagi siswa/generasi muda; meningkatnya transaksi uang non tunai.

Penerima manfaat: Masyarakat dan pemerintah manfaat internal / manfaat eksternal adalah mengatasi persoalan, memenuhi kebutuhan dan memperbaiki sistem.

Pekanbaru Ruang kendali untuk penanganan situasi-situasi Command penting di Kota Pekanbaru.

Center

Mal

Pelayanan

Publik

Pekanbaru
Menggabungkan berbagai jenis pelayanan pada satu tempat, penyederhaan dan prosedur serta integrasi pelayanan pada Mal Pelayanan Publik akan memudahkan akses masyarakat dalam mendapat berbagai jenis pelayanan, serta meningkatkan kepercayaan masyarakat kepada penyelenggara pelayanan publik. 
Kota Pekanbaru telah banyak menyediakan layanan $E$ - respon netizen terhadap kota Pekanbaru, penelitian ini government to citizen sebagai bentuk penerapan Smart menggunkan metode Social Network Analysis (SNA), City Madani, akan tetapi belum adanya penelitian yang Tujuan dari metode ini diterapkan dapat membantu melihat kesiapan masyrakat dalam menghadapi Smart mengelola data dan membuat sebuah analisa yang City di Pekanbaru. Maka dari itu diperlukan penelitian menghasilkan node graph agar pemerintah Pekanbaru yang melihat kesiapan masyarakat Kota Pekanbaru. dapat memanfaatkan hasil penelitian ini untuk melihat Penelitian ini akan melihat kesiapan dari media sosial apa saja yang harus dilakukan dengan melihat opini atau Twitter, dan melakukan analisa menggunakan Social interaksi yang dilakukan netizen terhadap 6 pilar yang Network Analysis (SNA). SNA merupakan suatu proses diusung oleh kota Pekanbaru untuk menghadapi Smart yang menelaah struktur sosial melalui penggunaan City.

Network Science. Network Science merupakan bidang kajian akademik baru yang mempelajari jaringan kompleks seperti jaringan telekomunikasi, jaringan komputer, jaringan biologis, dan jaringan sosial. Kajian ini mendasarkan dirinya pada Graph Theory [21]. Penelitian terkait dengan SNA, dilakukan untuk melihat interaksi antar aktor di media sosial salah satunya pada hastag "\#4niesKingOfDrama" [22]. Penelitian ini melihat Degree Centrality, centrality Betweenness, Closeness Centrality, dan Follower Rank. Dengan menggunakan metode SNA ini dapat menampilkan node graph untuk mengetahui seberapa banyak interaksi yang terjadi dan apa saja yang sedang dibicarakan oleh netizen terhadap kota pekanbaru. Social Network Analysis (SNA) dapat menganalisa dan memberikan informasi berupa node graf yang diperlukan oleh pemerintah Kota Pekanbaru untuk menerapkan Smart City.

\section{Metode Penelitian}

\subsection{Social Network Analysis (SNA)}

Social Network Analysis memiliki beberapa properti jaringan guna memetakan interaksi yang dapat membantu untuk meningkatkan penciptaan management knowledge di organisasi [26]. Adapun beberapa properti jaringan pada SNA dijelaskan pada tabel 2.

Table 2. Penjelasan Properti Jaringan

\begin{tabular}{|c|c|c|}
\hline No & Properti Jaringan & Deskripsi \\
\hline 1 & Nodes & $\begin{array}{l}\text { Mempresentasikan posisi aktor } \\
\text { dalam jaringan }\end{array}$ \\
\hline 2 & Edges & $\begin{array}{l}\text { Mempresentasikan interaksi antar } \\
\text { dua aktor atau lebih }\end{array}$ \\
\hline 3 & Average Degree & $\begin{array}{l}\text { Rata-rata jumlah interaksi yang } \\
\text { dimiliki oleh actor dalam } \\
\text { keseluruhan jaringan }\end{array}$ \\
\hline 4 & Diameter & $\begin{array}{l}\text { Jarak maksimal dalam keseluruhan } \\
\text { jaringan }\end{array}$ \\
\hline 5 & Average Path Length & $\begin{array}{l}\text { Jarak rata-rata antar keseluruhan } \\
\text { actor dalam jaringan }\end{array}$ \\
\hline
\end{tabular}

Penelitian terkait dengan penerapan Smart City di Pekanbaru sudah dilakukan oleh beberapa peneliti. Penelitian yang dilakukan [23] mengatakan bahwa kurangnya sosialisasi masyarakat belum massif dan maksimal membuat implementasi Smart City Madani dirasa tidak tersosialisasi dengan sempurna di tataran masyarakat umum. Kemudian penelitian lain mengatakan bahwa kehadiran kartu smart madani dan kartu identitas anak yang telah diterapkan oleh kota pekanbaru sudah tepat, namun masih banyak yang harus dilakukan untuk menutupi kekurangan yang ada pada Kota Pekanbaru seperti masalah kemiskinan yang harusnya lebih didahulukan melalui inovasi yang dikembangakan oleh pemerintah Pekanbaru [24]. Kedua penelitian tersebut dilakukan berdasarkan observasi dan pengamatan langsung. Penelitian yang dilakukan pada penelitian ini mengambil dari sudut pandang yang berbeda yaitu melalui sosial media.

Penelitian ini dilakukan dengan cara mengambil data pada media sosial twitter dan data yang di ambil melalui hashtag pada twitter yang berkaitan dengan kota Pekanbaru, untuk menentukan masyarakat Pekanbaru siap atau tidak dilihat berdasarkan 3 (tiga) indikator kesiapan masyarakat yaitu, Pengetahuan, Sikap, dan Respon [25]. Berdasarkan indikator tersebut penelitian ini hanya mengacu pada 2 indikator yaitu, Sikap dan Respon, peneliti melihat bagaimana interaksi masyarakat dimedia sosial twitter melalui sikap dan

Sumber: [27]

Social Network Analysis memiliki beberapa konsep pendekatan yaitu selain menggambarkan pola yang terbentuk melalui hubungan dari antar node maupun aktor, yang lebih sering digunakan pada SNA dalam menentukan node sentral disebuah network dengan menghitung beberapa nilai centrality yang umum dihitung adalah. [28] :

1. Degree centrality yaitu menghitung jumlah interaksi yang dimiliki oleh sebuah node. Untuk menghitung nilai degree centrality dari node ni dapat dilakukan dengan menggunakan rumus 1 .

$C \mathrm{D}(\mathrm{n} i)=\mathrm{d}(\mathrm{n} i)$

Dengan $\mathrm{d}(\mathrm{n} i)$ adalah banyaknya informasi yang dimiliki oleh node ni dengan node lain di dalam network.

2. Betwenness centrality menghitung seberapa sering sebuah node dilewati oleh node lain untuk menuju ke sebuah node tertentu di dalam jaringan. Nilai ini berfungsi untuk menentukan peran aktor yang menjadi jembatan penghubung interaksi di dalam network. Untuk menghitung nilai degree centrality dari sebuah node dapat dilakukan dengan menggunakan rumus 2 . 


$$
\mathrm{CB}(\mathrm{n} i)=\frac{\sum \mathrm{g} j k(\mathrm{n} i)}{\mathrm{g}_{j k}}
$$

Dengan $\sum \mathrm{g} j k(\mathrm{n} i)$ adalah jumlah terpendek dari $\mathrm{j}$ ke node $\mathrm{k}$ yang melewati node $\mathrm{i}$ dan $\mathrm{g} j k$ adalah banyaknya jalur terpendek antar 2 buah node dalam network.

3. Closeness centrality menghitung jarak rata-rata antara suatu node dengan seluruh node lain di dalam jaringan atau dalam kata lain mengukur kedekatan sebuah node dengan node lain. Dalam sebuah jaringan dengan $g$ node, closeness centrality dari node $\mathrm{n} i$ adalah sebagai berikut:

$$
\operatorname{Cc}(\mathrm{n} i)=\left[\frac{\mathrm{N}-1}{\sum d(\mathrm{n} i, \mathrm{n} j \mathrm{j}}\right]
$$

Dengan $\mathrm{N}$ adalah jumlah node di dalam jaringan dan $\sum d(\mathrm{n} i, \mathrm{n} j)$ adalah jumlah jalur terpendek yang menghubungkan node $\mathrm{n} i$ dan $\mathrm{n} j$.

4. Eigenvector centrality melakukan pengukuran yang memberikan bobot lebih tinggi pada node yang terhubung dengan node lain yang juga memiliki nilai centrality tinggi. Untuk menghitung nilai eigenvector centrality dari sebuah node dapat dilakukan dengan menggunakan rumus 4 .

$$
\begin{aligned}
& C i(\beta)=\sum(\mathrm{a}+\beta c j) A j i \\
& C(\beta)=\mathrm{a}(\mathrm{I}-\beta A)-1 A \mathrm{l}
\end{aligned}
$$

Dengan a adalah konstanta normalisasi (skala vektor) dan $\beta$ melambangkan seberapa banyak suatu node mempunyai bobot centrality dalam node yang juga memiliki nilai centrality yang tinggi.

Dimana A adalah adjacency matrix, I adalah identity matrix dan 1 adalah matrix. Besarnya $\beta$ adalah radius power dari suatu node. Jika $\beta$ positif, maka mempunyai ikatan centralityyang tinggi dan terhubung dengan orang-orang yang bersifat sentral. Sedangkan jika $\beta$ negatif, maka mempunyai ikatan centrality tinggi namun terhubung dengan orang-orang yang tidak
central. Jika $\beta=0$, maka akan didapat degree centrality.

\subsection{Metodologi Penelitian}

Dalam melalukan sebuah penelitian data dan informasi bersifat objektif yang akan digunakan sebagai titik acuan dalam penelitian, dengan adanya data-data tersebut diharapkan penelitian yang dihasilkan adalah penelitian yang berkualitas. Peroses dalam melakukan penelitian ini digambarkan dalam sebuah flowchart pada Gambar 1 .

\subsection{Pengumpulan Data}

Dalam tahap ini dilakukan proses ekstraksi atau menggunakan software rapidminer dan disimpan pengumpulan data dengan cara crawling dengan bantuan sebelumnya dengan menggunakan format .cvs berbasis software RapiddMiner. Pada Rapidmnner membutuhkan akases API Twitter. API Twitter ini digunakan sebagai akses crawling data yang diberikan twitter. Data yang diambil adalah data unggahan pengguna yang mengandung kata hastag "Pku, infopku, \#pekanbaru, \#pkusmartcity", dan minimal memiliki satu buah interaksi yang terjadi antar dua aktor di dalam jaringan. Gambar 2 merupakan proses pengambilan data pada penelitian ini menggunakan Rapiddminer.

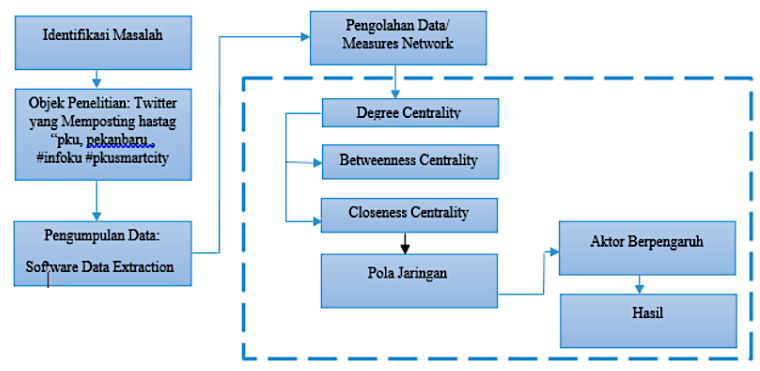

Gambar 1. Alur Metodologi Penelitian

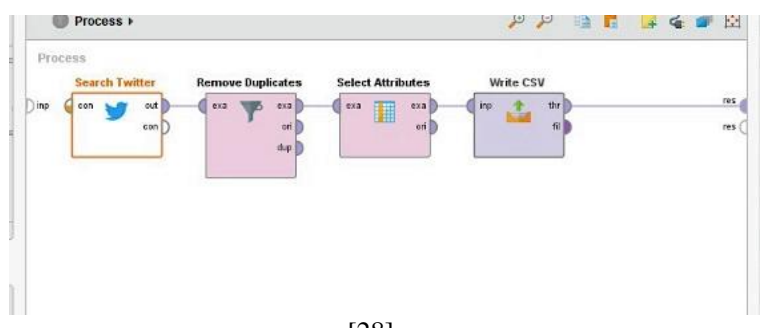

Gambar 2. Proses Crawling Data

Pada gambar 2 terdapat beberapa tools yang digunakan, berikut ini merupakan penjelasan dari tools yang digunakan. a. Search twitter guna menghubungkan pada akun media sosial twitter untuk menghubungkan data yang ingin crawling, kemudian hubungkan Search twitter pada operator. b. Remove duplicate untuk menghilangkan apa saja yang tidak diperlukan dalam melakukan crawling data. c. Select attribute untuk memilih attribute apa saja yang akan dipakai pada saat crawling data. d. Write CSV untuk menghasilkan data dengan formar csv.

\subsection{Pengolahan data}

Tahap ini merupakan tahap pengolahan data interaksi jaringan. Pola interaksi divisualisasikan dengan menggunakan metode graph dengan tipe undirected. Setelah visualisasi pola jaringan interaksi didapatkan selanjutkan dilakukan penghitungan nilai atribut jaringan yang menghitung delapan atribut yakni total nodes, total edges, average degree, average weighted degree, average path length, density, network diameter dan number of community. Berikut ini merupakan proses pengolahan data yang dilakukan.

Import data set jaringan yang didapat dari crawling data 
text. Kemudian dataset dipisah menjadi dua bagian, interaksi yang tinggi. Berikut ini merupakan sample pertama import data set nodes dan tahap kedua import perhitungan yang dilakukan. data set edges. (Dataset nodes merupakan daftar nama aktor yang terdapat pada jaringan, sedangkan dataset edges merupakan data relasi atau interaksi yang terjadi antar nodes di dalam jaringan.

Pilihlan algoritma visualisasi yang ingin digunakan. Algoritma ini nantinya berfungsi sebagai penentu tata letak node-node yang divisualisasikan di dalam sociogram. Pemilihan algoritma juga berpengaruh terhadap bentuk visualisasi jaringan yang akan dihasilkan. Dalam penelitian ini algoritma yang digunakan adalah layout Fruchterman Reingold.

Kemudian mengatur konfigurasi algoritma dengan cara mengubah kolom atribut seperti area, gravity dan speed yang tersedia pada properties windows sesuai dengan konfigurasi yang akan digunakan.

Kemudian mempersonalisasi jaringan yang telah divisualisasikan. Dalam proses ini akan dilakukan pengaturan terhadap tampilan warna, bentuk, pemberian label pada nodes di dalam jaringan dan juga dapat dilakukan pengaturan tebal tipis sebuah garis edges antar node dan pemberian nama pada edges tersebut.

Selanjutnya Menghitung nilai property jaringan. Dalam penelitian ini dilakukan penghitungan terhadap nilai atribut properti jaringan berupa nilai Total Node, Total Edges, Average Degree, Average Weighted Degree, dan Network Diameter, Seluruh atribut tersebut dapat dihitung dengan meng-klik satu per satu tombol dalam kolom setting pada statistic windows.

Kemudian Menampilkan ranking dari nodes yang memiliki pengaruh atau nilai interaksi yang paling tinggi di dalam jaringan. Untuk ini dapat dilakukan dengan dua cara yaitu, yang pertama dengan melihat langsung pada windows data table, dan yang kedua dengan melakukan konfigurasi tampilan dengan mengubah size node atau label node dalam gambar visualisasi jaringan sesuai dengan urutan nilai yang dimiliki oleh nodes tersebut (semakin besar nilai yang dimiliki node maka semakin besar pula tampilan node tersebut di dalam gambar visualisasi jaringan). Cara yang kedua dapat dilakukan dengan mengubah konfigurasi pada appereance window.

Yang terakhir yaitu eksport gambar visualisasi tersebut dengan ekstensi file .pdf, .png dan .svg. Hasil penghitungan data juga dapat di eksport dengan mengakses menu pada data table window hasil olah data akan berupa file dengan format ekstensi .csv.

\subsection{Perhitungan Nilai Centrality}

Pada tahap ini merupakan tahap penghitungan nilai centrality (degree centrality, closeness centrality, dan Diketahui $\mathrm{n}=3$ dan $\mathrm{d}(1,1,3, \ldots 1)$ jadi normalisasi betweeness centrality) node atau aktor untuk Closeness Centrality: $\mathrm{Cc}(1): 3 /(1+1+3+3+2+1+2+2 . .+1)$ mengidentifikasi aktor berpengaruh dengan jumlah $=3 / 54=0.055108$
Perhintungan degree centrality pada hastag pekanbaru dengan node@Mahardika Doks dimana perhitungan degree centrality yang dilakukan dengan bantuan software gephi di dapat 3 interaksi yang terjadi yang terlihat pada gambar 3 .

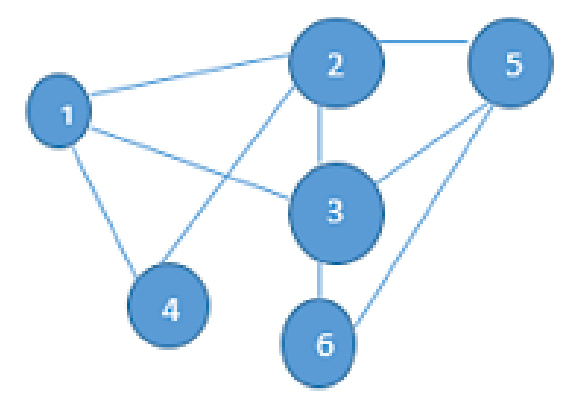

Gambar 3. Interaksi Degree Centrality

Dari gambar 3 diketahui pada node 1 dapat dilihat degree centrality terjadi 4 interaksi node, Jika dilakukan perhitungan manual dengan Rumus 1 , maka didapatkan: $\mathrm{d}(n i ́)=4$ dan $\mathrm{g}=1$ maka normalisasi degree centrality : $4 /(1-1)=4$

Kemudian untuk menghitung Closeness Centrality pada hastag pekanbaru dengan node @Mahardika Doks dimana perhitungan Closeness Centrality yang dilakukan dengan bantuan software gephi di dapat 0.055108 yang terjadi, pada gambar 4 merupakan Closeness Centrality yang terjadi pada salah satu node.

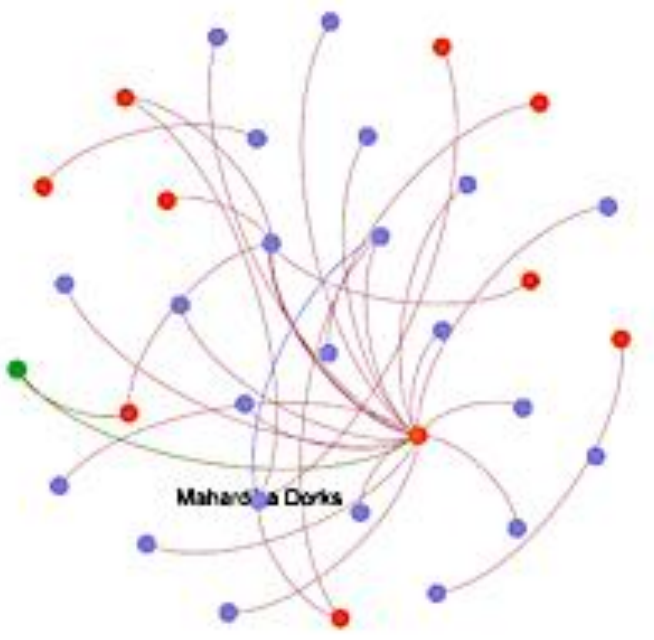

Gambar 4. Closeness Centrality

Kemudian dilakukan perhitungan manual guna melihat bagaimana interaksi yang terjadi jika dilakukan perhitungan menggunakan rumus 2 : 
Kemudian perhitungan betweeness centrality pada secara otomatis melalui software Gephi. Tabel 3 hastag pekanbaru dengan node @Mahardika Doks merupakan perhitungan yang didapatkan hasil nilai dari dimana perhitungan betweeness centrality yang masing-masing properti jaringan pada jaringan 4 hastag dilakukan dengan bantuan software gephi di dapat yang digunakan.

0.0301205 yang terjadi, hal ini bisa dilihat pada gambar 4. Untuk melihat interaksi yang terjadi maka dilakukan perhitungan menggunakan rumus 3. Dari gambar 4 dapat dilihat bobot nilai node berdasarkan seberapa banyak node i dilalui oleh dua node lain dalam graf berdasarkan jalur terpendek, Maka dapat diketahui: $\mathrm{ni}=54, \mathrm{~g}=1$ maka dapat dihitung dengan 54/ $[(1-1)(1-2) / 2]=$ 0.0301205

\section{Hasil dan Pembahasan}

Penelitian ini dilakukan dengan memvisualisasikan data interaksi masyarakat terhadap Kota Pekanbaru di sosial media twitter. Dari data yang didapat dengan bantuan software rapidminer, kemudian data yang didapat akan disimpan dalam format .cvs. Penyimpanan data merupakan tahap selanjutnya setelah melakukan proses penarikan data atau crawling data twitter. Data tersebut merupakan data mentah yang kemudian akan dilakukan proses pengolahan menggunakan bantuan software Gephi 0.9.2. Tujuan dari penelitian ini untuk menganlisa kesiapan masyarakat Kota Pekanbaru dalam menghadapi Smart City. Dengan mengetahui seberapa banyak masyarakat yang berinteraksi terhadap Kota Pekanbaru di media sosial Twitter dan apa saja yang menjadi topik pembahasannya.

\subsection{Analisis Data}

Setelah melakukan proses crawling data, maka dilakukan perhitungan model jaringan dan pembuatan model jaringan interaksi masyarakat Kota Pekanbaru. Pembuatan visualisasi model jaringan ini dilakukan dengan bantuan software Gephi yang menggunakan 26 undirected graph yang mana cara kerja dari graph ini tidak mempertimbangakan arah tujuan antar node. Jenis graph ini tidak melihat indegree (node yang dituju) dan out degree (node asal). Layout graph yang di pilih dalam pembuatan model jaringan ini adalah Fruchterman Reingold. suatu algoritma yang menyatukan bagianbagian yang baik dari algoritma yang diarahkan gaya dan algoritma multi level untuk mengurangi kompleksitas algoritma. Ini merupakan salah satu algoritma yang bekerja sangat baik dengan jaringan besar. Hasil dari pembuatan jaringan yaitu mendapatkan 4 model jaringan yang mana menunjukan setiap actor atau node yang saling berinteraksi satu degan lainnya di mana antar node membicarakan mengenai Kota Pekanbaru.

\subsection{Perbandingan Properti Jaringan}

Sebelum dilakukan pembuatan visualisasi model jaringan, diperlukan perbandingan properti jaringan agar dapat dianalisa lebih lanjut. Perbandingan dilakukan

\begin{tabular}{|c|c|c|c|c|c|c|c|}
\hline 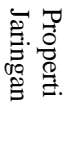 & 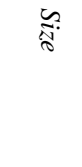 & 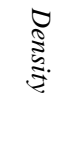 & 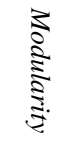 & 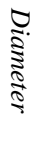 & 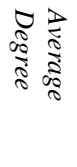 & 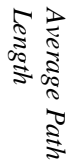 & 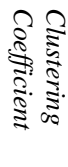 \\
\hline $\begin{array}{l}\text { Info } \\
\text { Pku }\end{array}$ & $\begin{array}{l}\text { Nodes: } \\
120 \\
\text { Edges: } \\
94\end{array}$ & 0.013 & 0.775 & 7 & 1.567 & 3.215 & 0.121 \\
\hline $\begin{array}{l}\text { Peka } \\
\mathrm{n} \\
\text { baru }\end{array}$ & $\begin{array}{l}\text { Nodes: } \\
126 \\
\text { Edges: } \\
75\end{array}$ & 0.01 & 0.934 & 2 & 1.19 & 1.662 & 0 \\
\hline $\begin{array}{l}\text { Pku } \\
\text { Smar } \\
\mathrm{t}\end{array}$ & $\begin{array}{l}\text { Nodes: } \\
33 \\
\text { Edges: }\end{array}$ & 0.057 & 0.471 & 5 & 1.818 & 2.47 & 0 \\
\hline City & $\begin{array}{l}36 \\
\text { Nodes: } \\
86 \\
\text { Edges: } \\
57\end{array}$ & 0.016 & 0.898 & 2 & 1.326 & 1.716 & 0 \\
\hline
\end{tabular}

Tabel 3 menunjukan perbandingan dari nilai properti jaringan yang berisikan interaksi user di media sosial twitter mengenai Kota Pekanbaru dalam rentang waktu penelitian dari juli 2020 sampai dengan Agustus 2020. Properti yang dibandingkan pertama adalah size yang mana semakin besar node maka aktor yang terjalin di dalam jaringan sosial semakin banyak. Hal seperti ini menandakah bahwa banyak aktor yang sedang membicara mengenai Kota Pekanbaru. Nilai size yang tertinggi adalah Pekanbaru yaitu 126 nodes yang menunjukan terdapat 126 aktor yang membicarakan Pekanbaru di media sosial twitter disusul InfoPku yaitu sebanyak 120 nodes dan akutansi sebanyak 100 nodes. Edges adalah interaksi yang terjadi antar aktor. Semakin tinggi nilai edges menunjukan bahwa banyak percakapan tentang Kota Pekanbaru tersebut di media sosial twitter. Infopku memiliki niali edge tertingi yaitu sebanyak 94 edges dan yang kedua yaitu Pekanbaru dengan 75 edges di susul hastag pku dengan 66 edges.

Properti jaringan kedua adalah density semakin banyak aktor dalam jaringan menghasilkan nilai density yang besar. Semakin besar nilai density dari sebuah jaringan maka aktor-aktor yang ada di dalam jaringan lebih saling terhubung. Dari empat hastag yang mendapatkan nilai density paling besar yaitu pkusamartcity sebesar 0.057 yang kedua yaitu pku 0.16 dan yang ketiga yaitu Pku 0.026 .

Properti jaringan yang ketiga adalah modularity. Semakin tinggi nilai modularity maka lebih jelas 
jaringan yang terbentuk. Setiap jaringan yang pekanbaru dengan nilai 1.662 selanjutnya yaitu Pku didapatkan dapat diartikan sebagai komunitas yang dengan nilai 1.716 dan pkusmartcity dengan nilai 2.47. berbeda sehingga mendapatkan spsefikasi lebih terhadap produk di setiap komunitas. Jaringan hastag yang di peringkat pertama nilai modularity adalah pekanbaru yaitu dengan nilai 0.934 selanjutnya pku dengan nilai 0.898 dan InfoPku dengan nilai 0.775

Properti jaringan yang terakhir adalah clustering coefficient. Clustering coefficient menunjukan aktor yang berkaitan dalam properti jaringan. Aktor dalam properti jaringan pada hastag yang paling tinggi yaitu Pekanbaru yang mana aktor didalamnya saling terkait Properti jaringan yang keempat adalah diameter. satu dengan yang lainnya, maka informasi yang Diameter yaitu jarak antar nodes dalam suatu jaringan. dibicarakan lebih awal diketahui.

Semakin kecil diameter pada jaringan maka akan mudah node saling berinteraksi karena jarak antar node sangat pendek maka pekanbaru dan Pku di peringkat pertama

\subsection{Visualisasi Data dan Perhitungan Properti} Jaringan

dengan nilai 2 selanjutnya yaitu, Pkusmartcity di Sebelum dilakukan perhitungan properti jaringan, peringkat kedua dengan nilai 5 dan InfoPku dengan terlebih dahulu dilakukan visualisasi jaringan diameter 7.

Properti jaringan kelima yaitu Average degree. Average degree memperlihatkan nilai antar hubungan aktor dalam sebuah jaringan social. Semakin besar nilai ratarata average degree maka semakin baik karena setiap aktor dalam jaringan saling berhubungan, sehingga penyebaran informasi lebih luas. Hastag Pkusamartcity terbesar yaitu dengan nilai 1.818 selanjutnya yaitu InfoPku dengan nilai 1.567 dan Pku dengan nilai 1.326. menggunkan software Gephi, perhitungan dilakukan secara otomatis menggunakan bantuan software gephi didapatkan hasil nilai dari masing-masing properti jaringan pada jaringan 4 hastag yang digunakan. Berikut ini bentuk visualisasi dari masing-masing 4 jaringan hastag dan perhitungan jaringan masing-masing hastag yang di dapat dari crawling data yang dilakukan di rapidminer:

Properti jaringan keenam Average path length yaitu Visualisi jaringan pada gambar 5 terlihat netizen atau semakin sedikit rata-rata jaringan akun yang dilewati masyarakat online Kota Pekanbaru banyak yang maka semakin baik karena setiap jaringan mempunyai menggunakan hastag ini untuk berbagai postingan hubungan yang kuat. Nilai dari average path length mengenai informasi terkait dengan Kota Pekanbaru. terkecil adalah pada interaksi 126 user mengenai

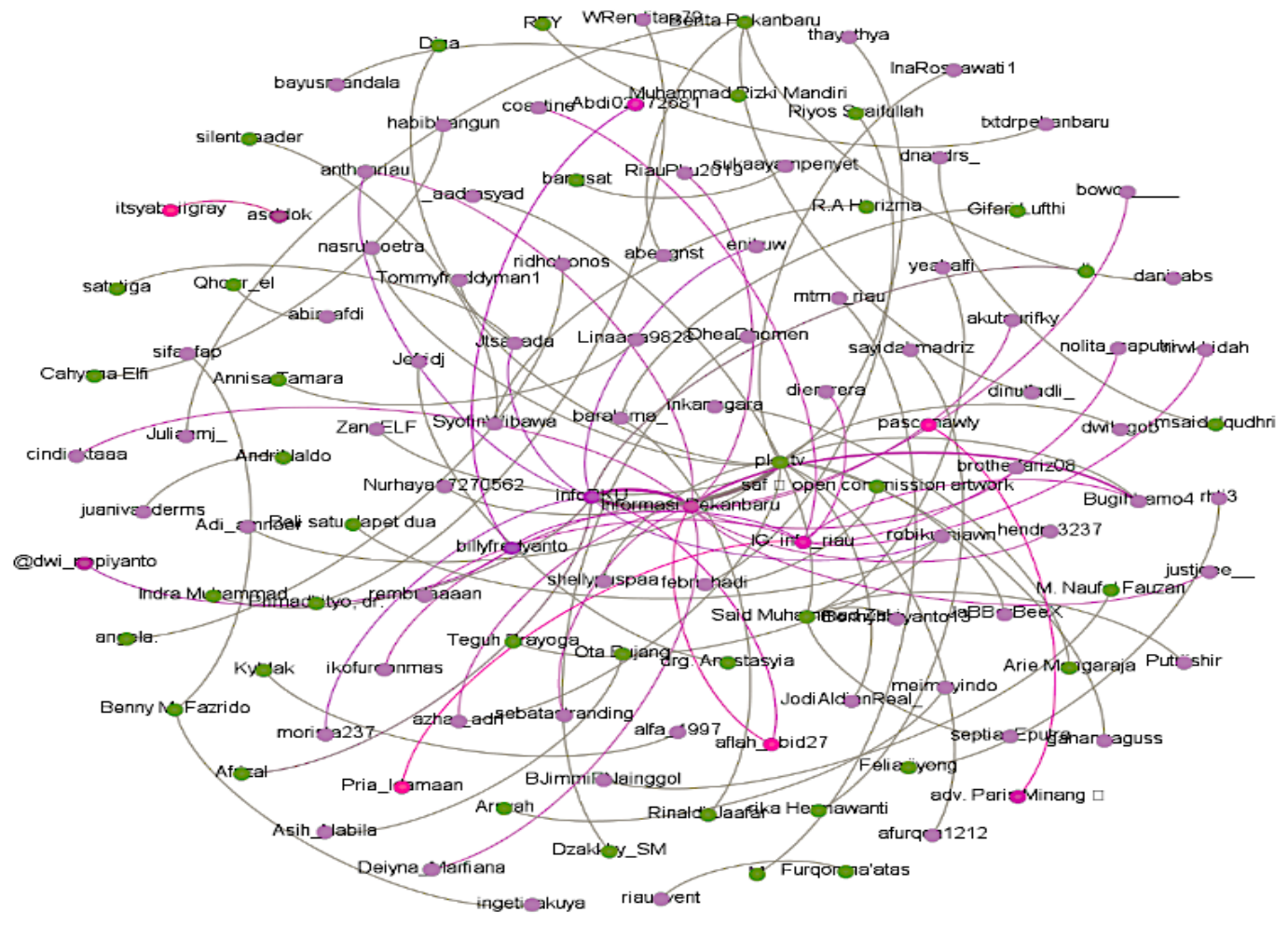

Gambar 5. Visualisasi Jaringan \#InfoPku 
Gambar 5 merupakan jaringan hastag dari InfoPku, Proses pemodelan jaringan ini menggunakan software Gephi dengan mengaplikasikan layout Fruchterman Reingold. Dari hasil pemodelan jaringan tersebut didapat aktor atau node yang saling berhubungan dengan node lain. Gambar ini menunjukan setiap node yang membicarakan mengenai Kota Pekanbaru dengan hastag "InfoPku" di media social Twitter.

\begin{tabular}{|c|c|c|c|c|}
\hline \multicolumn{5}{|c|}{ Tabel 4. Centrality \#InfoPku } \\
\hline \multirow{2}{*}{ Node } & 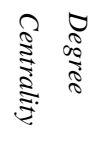 & 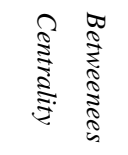 & 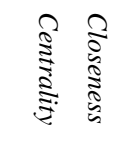 & 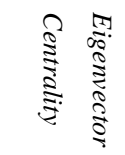 \\
\hline & 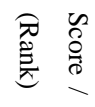 & 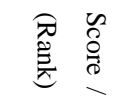 & 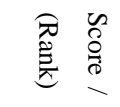 & 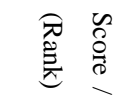 \\
\hline $\begin{array}{l}\text { @SunguikKusui } \\
\mathrm{k}\end{array}$ & $18 /(1)$ & $\begin{array}{l}0.538306 / \\
\text { (1) }\end{array}$ & $\begin{array}{l}0.714286 / \\
\text { (1) }\end{array}$ & $\begin{array}{l}1 \\
/(1)\end{array}$ \\
\hline $\begin{array}{l}\text { @ Mahardika } \\
\text { Dorks }\end{array}$ & $3 /(2)$ & $\begin{array}{l}0.055108 / \\
\text { (2) }\end{array}$ & $\begin{array}{l}0.301205 / \\
\text { (2) }\end{array}$ & $\begin{array}{l}0.061929 /( \\
2)\end{array}$ \\
\hline @ naneuntriaa & $2 /(3)$ & $\begin{array}{l}0.038642 / \\
\text { (3) }\end{array}$ & $\begin{array}{l}0.352113 / \\
\text { (3) }\end{array}$ & $\begin{array}{l}0.081445 /( \\
3)\end{array}$ \\
\hline @abcdefzaa & $2 /(4)$ & $\begin{array}{l}0.054772 / \\
\text { (4) }\end{array}$ & $\begin{array}{l}0.384615 / \\
\text { (4) }\end{array}$ & $\begin{array}{l}0.104131 /( \\
4)\end{array}$ \\
\hline
\end{tabular}

Tabel 4 menunjukan hasil perhitungan data hastag InfoPku melalui media sosial twitter menggunakan software Gephi 0.9.2 terhadap nilai degree centrality, betweeness centrality, closeness centrality dan eigenvector centrality maka diketahui bahwa aktor yang berpengaruh terhadap interaksi jejaring sosial adalah aktor@pku.tv yang unggul pada nilai degree centrality, betweeness centrality, eigenvector centrality dan closeness centrality.Akun @ pku.tv menjadi aktor paling berpengaruh dari total jumlah interaksi yang dihasilkan, kemudian akun tersebut menjadi penghubung atau jembatan bagi interaksi aktor lain di dalam jaringan dan unggul dalam hubungannya terhadap aktor berpengaruh lain di dalam jaringan. Aktor-aktor pendukung lain yang juga memiliki pengaruh yang cukup besar di dalam interaksi jejaring sosial Twitter adalah akun @Informasi Pekanbaru, @info_riau, @Said Muhammad Zaki.

\section{2. \#PkuSmartCity}

Berikut ini gambar 6 merupakan visualisasi jaringan pada \#PkuSmartcity. Pada gambar 6 terlihat bahwa masyarakat Kota Pekanbaru kurang tertarik untuk membahas smart city, hal ini terlihat hanya beberapa orang saja yang membahas smart city di media sosial Twitter.

Gambar 6 menunjukan setiap node yang membicarakan mengenai Kota Pekanbaru hastag "\#PkuSmartCity" di media social Twitter. Kemudian pada tabel 4 merupakan centrality pada hastag tersebut.

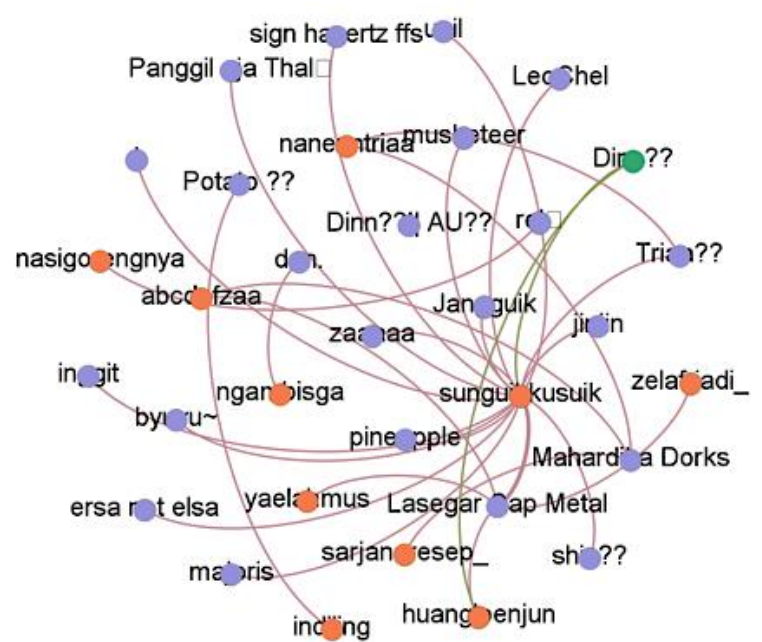

Gambar 6. Visualisasi jaringan \#PkuSmartCity

Pada tabel 5 dapat diketahui bahwa aktor yang berpengaruh terhadap interaksi jejaring sosial adalah aktor@SunguikKusuik yang unggul pada nilai degree centrality, betweeness centrality, eigenvector centrality dan closeness centrality. Akun @SunguikKusuik menjadi aktor paling berpengaruh dari total jumlah interaksi yang dihasilkan, kemudian akun tersebut menjadi penghubung atau jembatan bagi interaksi aktor lain di dalam jaringan dan unggul dalam hubungannya terhadap aktor berpengaruh lain di dalam jaringan. Aktor-aktor pendukung lain yang juga memiliki pengaruh yang cukup besar di dalam interaksi jejaring sosial Twitter adalah akun @Mahardika Dorks, @byuyu , @abcdefzaa.

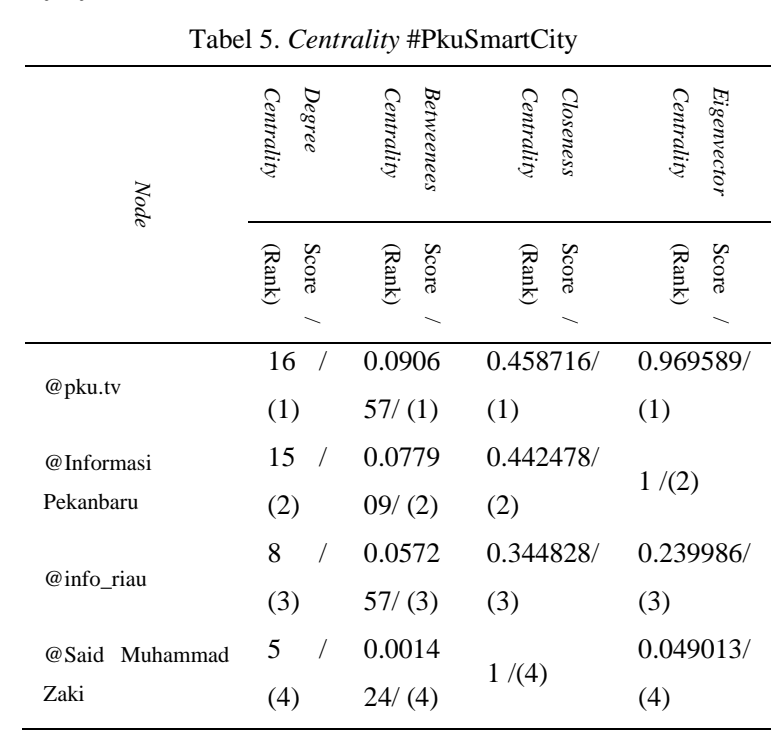

3. \#Pekanbaru

Hastag selanjutnya yaitu Pekanbaru, pada gambar 4 terlihat sudah mulai banyak masyarakat yang membahas Kota ini. 


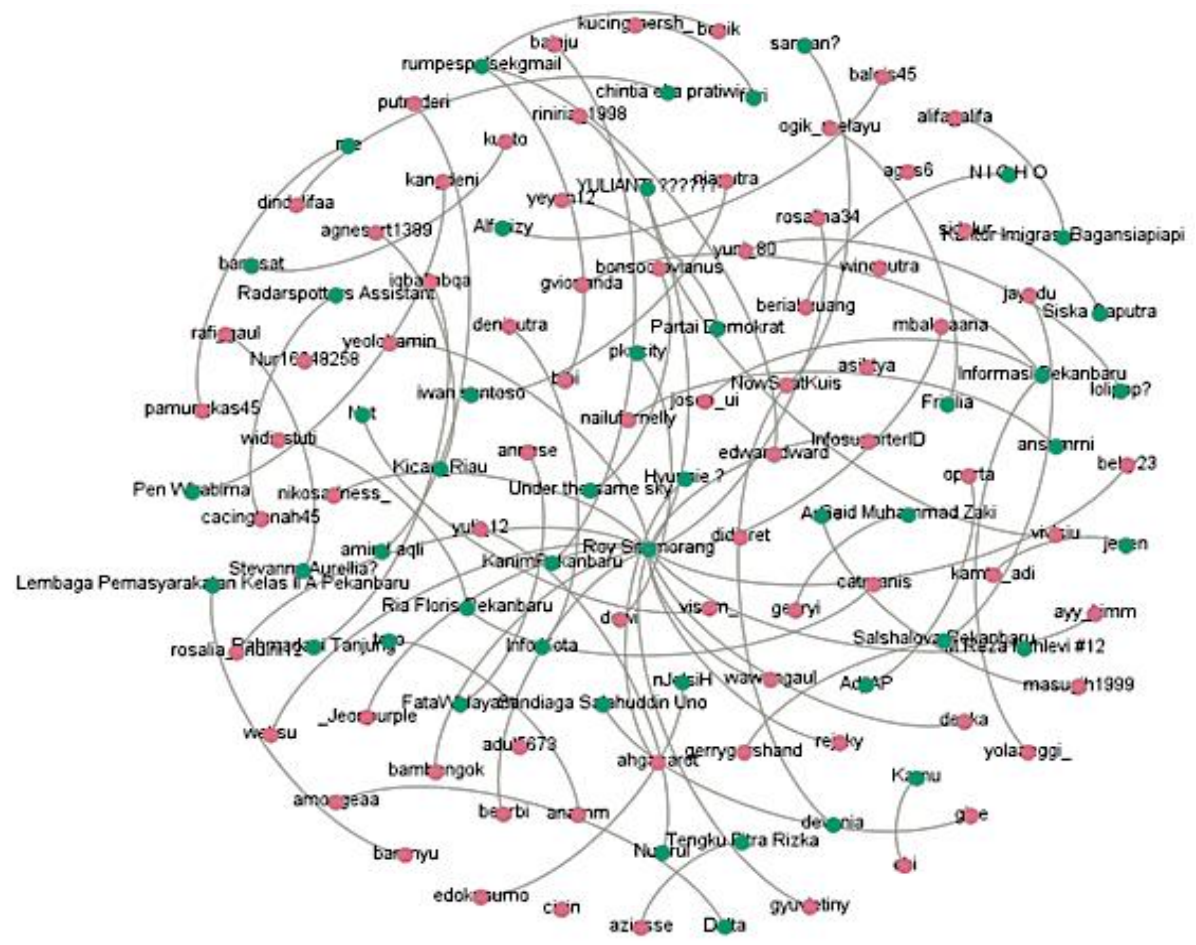

Gambar 7. Visualisasi jaringan \#Pekanbaru

Gambar 7 menunjukan setiap node yang membicarakan hubungannya terhadap aktor berpengaruh lain di dalam mengenai Kota Pekanbaru dengan hastag "Pekanbaru" jaringan. Aktor-aktor pendukung lain yang juga di media social Twitter. Tabel 5 merupakan centrality memiliki pengaruh yang cukup besar di dalam interaksi pada hastag pekanbaru. jejaring sosial Twitter adalah akun @NSPKU, @Bandara SSK 2 PKU, @Jaka Mhd Murfi.

Tabel 6. Centrality \#Pekanbaru

\begin{tabular}{|c|c|c|c|c|}
\hline \multirow[t]{2}{*}{ Node } & 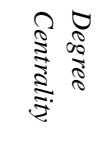 & 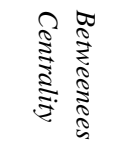 & 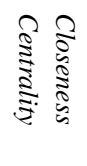 & 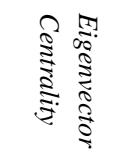 \\
\hline & 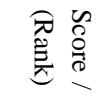 & 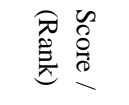 & 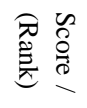 & 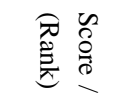 \\
\hline $\begin{array}{l}@ \text { Roy } \\
\text { Situmorang }\end{array}$ & $17 /(1)$ & $\begin{array}{l}0.019048 / \\
(1)\end{array}$ & $1 /(1)$ & $/(1)$ \\
\hline $\begin{array}{l}\text { @ Informasi } \\
\text { Pekanbaru }\end{array}$ & $3 /(2)$ & $\begin{array}{l}0.00042 \\
/(2)\end{array}$ & $1 /(2)$ & $\begin{array}{l}0.028094 / \\
\text { (2) }\end{array}$ \\
\hline $\begin{array}{l}@ \text { Ria Floris } \\
\text { Pekanbaru }\end{array}$ & $2 /(3)$ & $\begin{array}{l}0.00014 \\
/(3)\end{array}$ & $1 /(3)$ & $\begin{array}{l}0.015266 / \\
\text { (3) }\end{array}$ \\
\hline @ Alfarizy & $1 /(4)$ & $\begin{array}{l}0 \\
(4) \\
\end{array}$ & $1 /(4)$ & $\begin{array}{l}0.006074 / \\
(4)\end{array}$ \\
\hline
\end{tabular}

\section{4. \#Pku}

Pada gambar 8 terlihat bahwa penggunaan \#Pku lebih sedikit dibandingkan dengan \#Pekanbaru, hal ini dikarenakan masyarakat online dipekanbaru belum terlalu familiar dengan singkatan Kota Pekanbaru, yaitu PKU.

Gambar 8 menunjukan setiap node yang membicarakan mengenai Kota Pekanbaru dengan kata kunci "Pku" di media sosial Twitter

Dari Tabel 7 diketahui bahwa aktor yang berpengaruh terhadap interaksi jejaring sosial adalah aktor @ Roy Situmorang yang unggul pada nilai degree centrality, betweeness centrality, eigenvector centrality dan closeness centrality. Akun @Roy Situmorang menjadi aktor paling berpengaruh dari total jumlah interaksi yang

Tabel 6 diketahui bahwa aktor yang berpengaruh dihasilkan, kemudian akun tersebut menjadi terhadap interaksi jejaring sosial adalah aktor penghubung atau jembatan bagi interaksi aktor lain di @ ahmaddani yang unggul pada nilai degree centrality, dalam jaringan dan unggul dalam hubungannya terhadap betweeness centrality, dan closeness centrality. Akun aktor berpengaruh lain di dalam jaringan. Aktor-aktor @ahmaddani menjadi aktor paling berpengaruh dari pendukung lain yang juga memiliki pengaruh yang total jumlah interaksi yang dihasilkan, kemudian akun cukup besar di dalam interaksi jejaring sosial Twitter tersebut menjadi penghubung atau jembatan bagi adalah akun @Informasi Pekanbaru, @Ria Floris interaksi aktor lain di dalam jaringan dan unggul dalam Pekanbaru, @Alfarizy. 


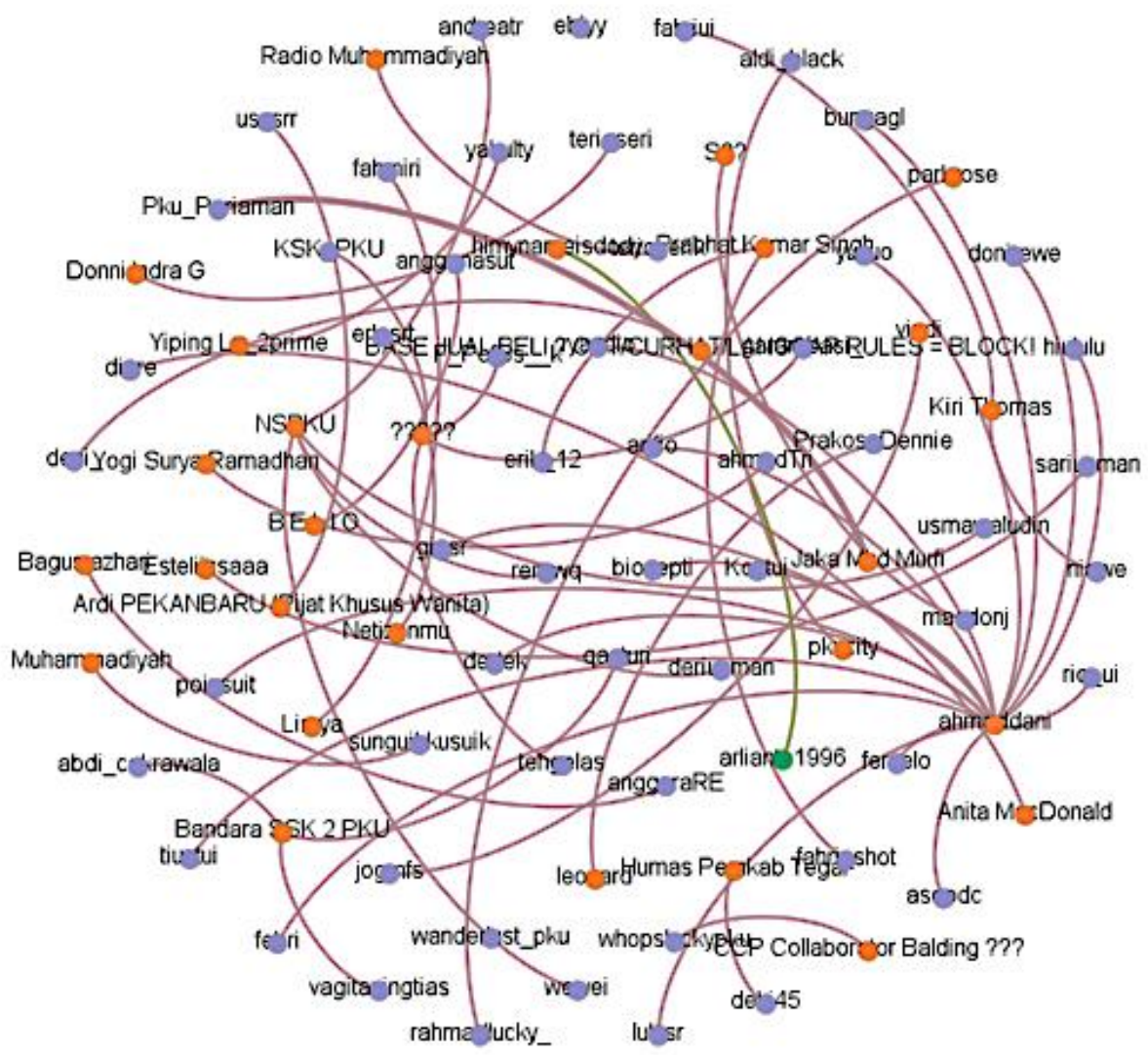

Gambar 8. Visualisasi jaringan \#Pku

.Tabel 7. Centrality \#Pku

\begin{tabular}{|c|c|c|c|c|}
\hline \multirow[t]{2}{*}{ Node } & 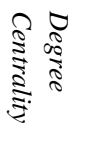 & 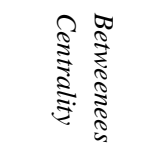 & 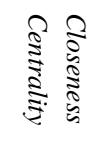 & 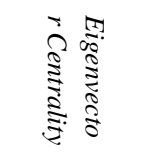 \\
\hline & 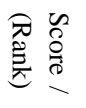 & 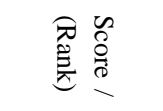 & 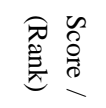 & 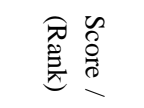 \\
\hline @ahmaddani & $16 /(1)$ & $0.034423 /(1)$ & $1 /(1)$ & $/(1)$ \\
\hline @NSPKU & $5 /(2)$ & / (2) & $1 /(2)$ & $/(2)$ \\
\hline $\begin{array}{l}\text { @Bandara SSK } \\
2 \text { PKU }\end{array}$ & $3 /(3)$ & $0.000861 /(3)$ & $\begin{array}{l}0.00286 \\
9 /(3)\end{array}$ & $0.030689 /(3)$ \\
\hline $\begin{array}{l}\text { @ Jaka } \quad \text { Mhd } \\
\text { Murfi }\end{array}$ & $2 /(4)$ & / (4) & $1 /(4)$ & $0.006483 /(4)$ \\
\hline
\end{tabular}

Berikut ini adalah model jaringan yang terbentuk, dan dapat dilihat pada gambar 9. Gambar 9 merupakan visualisasi jaringan gabungan dari keempat hastag yang dipilih untuk melihat kesiapan masyarakat Kota pekanbaru terhadap penerapan smart city.

Dari gambar 9 merupakan hasil visualisasi terhadap jaringan dari hastag pku, infopku, pekanbaru, pkusmartcity, dalam rentang waktu dua bulan yang menunjukkan hubungan antara nodes dan edges yang saling berinteraksi satau dengan yang lainnya. Visualisasi dibuat menggunakan aplikasi Gephi dengan menggunakan layout Fruchterman Reingold. Jenis graph yang digunakan adalah undirected graph, yaitu graph yang tidak mempertimbangkan arah hubungan antar node.

Dengan menggunakan software Gephi versi 0.9.1 dilakukan pengukuran nilai atribut jaringan dimana diperoleh dari empat atribut yang dibandingkan hastag pekanbaru unggul dalam enam atribut jaringan yakni jumlah node, jumlah edges, network diameter dan avarage path length. Sedangkan pkusmartcity unggul pada atribut density dan unggul dalam atribut average degree. Sehingga dapat dikatakan hastag pekanbaru memiliki performa penyebaran informasi "Smart City" yang paling baik dengan jumlah interaksi penyebaran informasi yang jauh lebih banyak jika dibandingkan dengan hastag infopku, pku, dan pkusmartcity, Pemerintah dapat menggunakan hastag pekanbaru di media sosial Twitter untuk meningkatkan jumlah interaksi penyebaran informasi "Smart City" dengan lebih cepat.

\subsection{Frequent Term}

Pada bagian ini akan dilihat terms hastag apa yang paling sering digunakan oleh masyarakat kota pekanbaru, berikut gambar 10 terms yang didapat. 


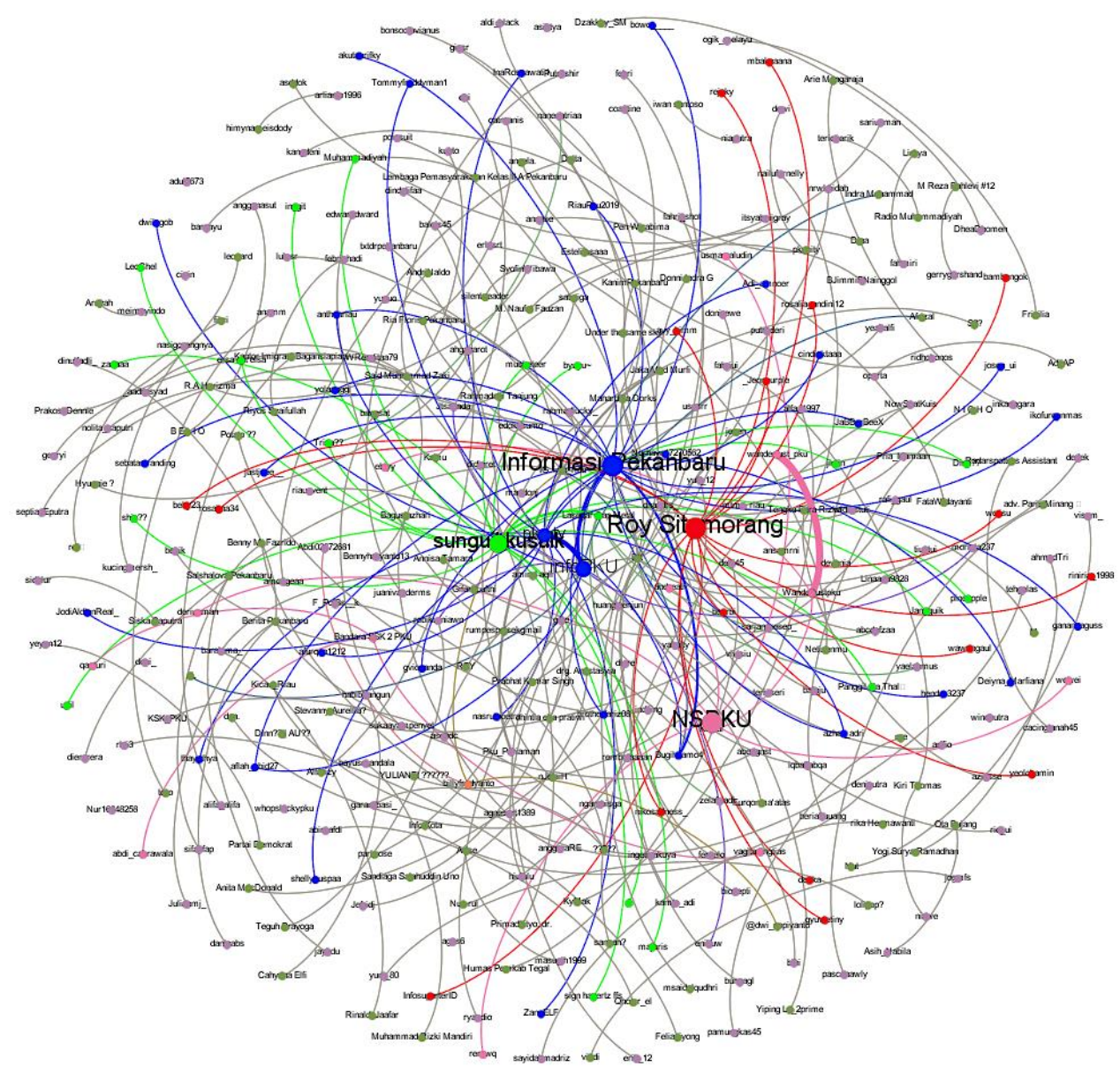

\#infopku \#pekanbaru \#pkusmarticity

Gambar 9. Visualisasi jaringan

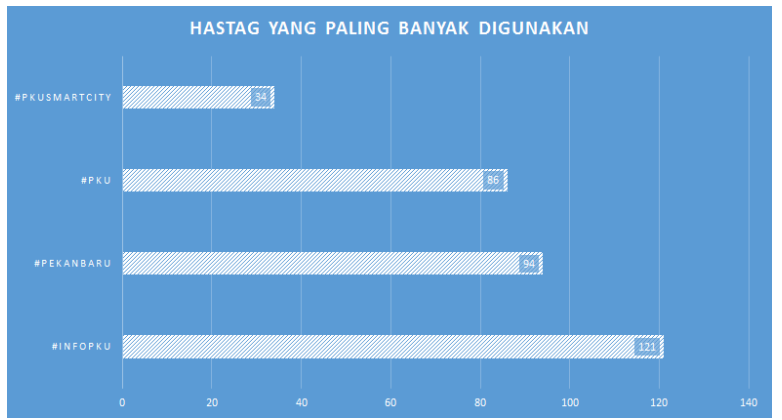

Gambar 10. Term hastag yang digunakan

Pada Gambar 10 dari terms teratas yaitu hastag pku dapat dilihat tiga terms yang palig sering muncul yaitu hastag infoku dengan frekuensi sebanyak 121, dan pekanbaru menjadi urutan kedua yang sering digunakan dengan frekuensi sebanyak 94 mention masyarakt kota Pekanbaru. Dari hastag di atas dapat dilihat apa saja yang sedang dibicarakanoleh masyarakat pekanbaru dari hastag yang digunakan, gambar 11 memperlihatkan apa yang menjadi topik utama dikalangan netizen pekanbaru dimedia sosial twitter.

\subsection{Word Cloud}

Word Cloud menggambarkan katakata yang paling sering muncul dan menjadi topik utama dari 337 tweets yang terdapat pada kedua akun twitter tersebut. Hampir sama dengan plot pada pembahasan 3 , tetapi terms atau topik teratas digambarkan melalui kumpulan kata. Kata yang paling sering muncul akan ditampilkan dalam ukuran yang lebih besar dari yang lainnya.

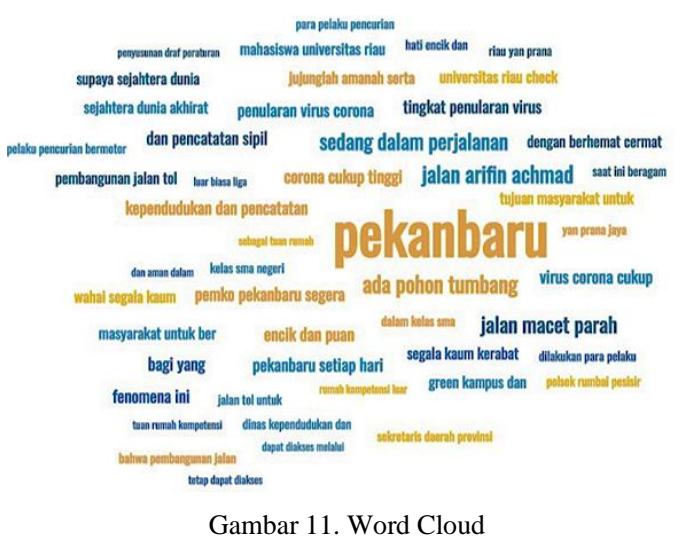

DOI: https://doi.org/10.29207/resti.v5i1.2742 
Pada gambar 13 dapat dilihat bahwa yang sering menjadi paling banyak mendapatkan nilai tertinggi yaitu topik pembahasan oleh netizen Pekanbaru, Word Cloud pekanbaru dengan total lima dari tujuh properti jaringan. memperlihatkan tiga kata teratas pada medi sosial twitter (b). Pekanbaru mendapatkan yang tinggi mengenai yaitu pekanbaru, pohon tumbang, dan jalan macet parah.

\subsection{Hasil dan Rekomendasi}

nodes yang artinya bahwa banyak pengguna atau netizen pekanbaru yang membahas mengenai pekanabru di media sosial twitter, dan edges yang membuktikan Dari penelitian yang telah dilakukan maka di dapat banyaknya interaksi antar user mengenai pekanbaru, bahwa masyarakat Kota Pekanbaru "Belum Siap" dalam Average Degree menunjukan setiap user atau aktor menghadapai Smart City Madani dilihat dari interaksi dalam jaringan mendapatkan nilai banyak yang saling masyarakat dimedia sosial Twitter. Terdapat 720.000 keterkaitan sehingga memperluas penyebaran informasi user pengguna twitter di Kota Pekanbaru sedangkan mengenai pekanbaru. (c). Berdasarkan pada hasil hitung masyarakat yang aktif berinteraksi terdapat 227 user. nilai degree centrality, betweeness centrality, closeness Hasil penelitian ini dilihat dari indikator kesiapan centrality dan eigenvector centrality yang dilakukan, masyarakat yang diteliti oleh [25], berdasarkan 2 (dua) maka akun @pku.tv pada hastag infopku di platform indikator kesiapan masyarakat yaitu, Sikap, dan Respon. twitter, akun @sunguikkusuik pada hastag Dengan Interprestasi kesiapan masyarakat yaitu 60-80\% pkusmartcity, akun@ahmadani pada hastag pekanbaru baik/siap dan 81-100\% Sangat siap, Ini menjadi faktor dan @ roy situmorang pada hastag Pku merupakan akunpendukung dari hasil penelitian penulis, dikarnakan dari akun yang paling berpengaruh terhadap berjalannya kedua indikator tersebut masyarakat Pekanbaru belum interaksi dalam jaringan interaksi penyebaran informasi memenuhi kreteria, sehingga masyarakat dikataka pada Kota Pekanabaru. Pihak pemerintah dapat belum siap dalam menghadapi perubahan Smart City memberdayakan akun-akun tersebut untuk Madani dilihat dari interaksi netizen dimedia sosial meningkatkan penyebaran informasi pada Kota twitter yaitu sekitar $0.031 \%$. Hal ini tentu sangat rendah Pekanabaru terutama mengenai Smart City Madani jika mengikuti standar yang telah ditentukan. Untuk dengan lebih maksimal. Pemberdayaan dapat dilakukan kedepannya pemerintah diharapkan melakukan dengan menjadikan akun-akun tersebut sebagai agen sosialisasi terhadap masyarakat Kota Pekanbaru agar atau mitra penyebaran informasi pada Kota Pekanabaru. masyarakat online atau netizen bisa lebih mengerti Pemerintah dapat menentukan seberapa banyak mengenai Smart City dan diharapkan masyakat siap unggahan yang perlu diunggah oleh akun tersebut untuk menghadapi perubahan yang akan dilakukan oleh menciptakan interaksi di dalam jaringan, kemudian pemerintah. Kota Pekanbaru juga bisa mengikuti pemerintah dapat menentukan pemuatan keyword apa penelitian yang dilakukan oleh [29] yang melakukan saja di dalam unggahan yang dibuat untuk pembotatan perangkingan pada kota-kota di Amerika mengoptimalkan pengkomunikasian sebuah informasi Serikat terkait dengan transportasi. Penelitian tersebut seperti penerapan teknologi yang ada, kinerja menggunakan metode yang mereka kembangankan dari pemerintah, program promosi dan informasi-informasi Technique for Order of Preference by Similarity to Ideal lain yang sedang menjadi fokus atau prioritas Solution (TOPSIS). Metode ini nantinya bisa digunakan pemerintah.

oleh pemerintah Kota Pekanbaru untuk menentukan prioritas pengembangan dari 6 pilar Smart City. Daftar Rujukan

Sehingga penerapan Smart City di Kota Pekanbaru dibangun berdasarkan skala prioritas tidak asal menerapkan jika program tersebut belum ada. Selain itu penerapan Smart City juga akan menggunakan biaya yang cukup besar [30]. Oleh karena itu penggunaan metode TOPSIS ini bisa digunakan sebagai alternatif untuk pembobotan prioritas yang dibutuhkan oleh masyarakat maupun pemerintah sehingga pengeluran untuk pembiyaan penerapan Smart City tidak langsung besar.

\section{Kesimpulan}

Berdasarkan dari hasil penelitian mengenai kesiapan masyarakat dalam menghadapi perubahan Smart City madani Kota Pekanbaru yang telah dilakukan, maka pada bagian ini peneliti dapat menyimpulkan. Bahwa (a). Berdasarkan hasil dari tabel dalam perhitungan properti jaringan didapatkan nilai jaringan dari setiap hastag. Setelah dilakukan perhitungan hastag yang

[1] Badan Pusat Statistika, Statistik Indonesia 2020 Statistical Yearbook of Indonesia 2020, no. April. Badan Pusat Statistik, 2020.

[2] Tim Apjii, "APJII Rilis Hasil Survei Pengguna Internet Indonesia Terbaru," Apjii, 2020. [Online]. Available: https://apjii.or.id/content/read/104/503/BULETIN-APJIIEDISI-74---November-2020. [Accessed: 20-Nov-2020]

[3] S. Kemp, Digital 2020 Global Digital Overview. 2020.

[4] A. Hasibuan and oris krianto Sulaiman, "Smart City, Konsep Kota Cerdas Sebagai Alternatif Penyelesaian Masalah Perkotaan Kabupaten / Kota," Bul. Tek., vol. 14, no. 2, pp. 127$135,2019$.

[5] E. L. Sofa and Subiyanto, "ROUTING ATTACKS PADA INTERNET OF THINGS BERBASIS SMART ROUTING ATTACKS DETECTION ON 6LoWPAN IN THE INTERNET OF THINGS USING SMART INTRUSION DETECTION SYSTEM,” J. Teknol. Inf. dan Ilmu Komput., vol. 7, no. 2, pp. 329-338, 2020.

[6] I. W. K. B. W, V. Suryani, and A. A. Wardhana, "A performance analysis of general packet radio service ( GPRS ) and narrowband internet of things ( NB-IoT ) in Indonesia," Kinet. Game Technol. Inf. Syst. Comput. Network, Comput. Electron. Control, vol. 5, no. 1, pp. 11-20, 2020. 
[7] M. A. Dar, "Security Architecture for Low Resource Devices in [19] Smart City using Cloud," Joiv (INTERNATIONAL J. INFORMATICS Vis., vol. 4, no. 3, pp. 144-147, 2020.

[8] A. C. Wardhana, Y. Nurhadryani, S. Wahjuni, D. I. Komputer, F. Informatika, and P. Korespondensi, "KNOWLEDGE MANAGEMENT SYSTEM BERBASIS WEB TENTANG BUDIDAYA WEB-BASED KNOWLEDGE MANAGEMENT SYSTEM CONCERNING HYDROPONIC CULTIVATION TO SUPPORT SMART SOCIETY," $J$. Teknol. Inf. dan Ilmu Komput., vol. 7, no. 3, pp. 619-628, 2020.

[9] M. Z. Abidin and R. Pulungan, "A Systematic Review of [21] Machine-vision-based Smart Parking Systems," Sci. J. Informatics, vol. 7, no. 2, pp. 213-227, 2020.

[10] B. E. Bitjoli et al., "Analisa Kesiapan Kota Cerdas (Studi Kasus: Pemerintah Kota Manado)," J. Tek. Inform., vol. 12, no. 1, 2017.

[11] E. Sorongan and Q. Hidayati, "Evaluation of Implementation EGovernment with Delone and Mclean," J. Ilm. Penelit. dan Penerapan Teknol. Sist. Inf., vol. 4, no. 1, pp. 22-37, 2020.

[12] R. Fadhlurrahman, M. C. Saputra, and A. D. Herlambang, "Evaluasi Penerapan E-government Di Pemerintah Kota Batu Menggunakan Kerangka Kerja Pemeringkatan E-government Indonesia ( PeGI )," J. Pengemb. Teknol. Inf. dan Ilmu Komput. Univ. Brawijaya, vol. 2, no. 12, pp. 5977-5982, 2018.

[13] N. L. Y. Lestari, Bandiyah, and K. W. D. Wismayanti, "Pengelolaan Pengaduan Pelayanan Publik Berbasis EGovernment (Studi Kasus Pengelolaan Pengagduan Rakyat Online Denpasar Pada Dinas Komunikasi dan Informatika Kota Denpasar Tahun 2014)," J. Ilm. Mhs. Citiz. Chart., vol. 1, no. 2 , pp. 1-12, 2015.

[14] R. Ramadhan, R. Arifianti, and R. Riswanda, "IMPLEMENTASI E-GOVERNMENT DI KOTA TANGERANG MENJADI SMART CITY (Studi Kasus Aplikasi Tangerang Live)," Responsive, vol. 2, no. 3, p. 89, 2020.

[15] R. Mahesa, G. Yudoko, and Y. Anggoro, "Dataset on the sustainable smart city development in Indonesia," Data Br., vol. 25, p. 104098, 2019.

[16] M. Tajuddin, "Model Blue Print Smart City Pemerintah Daerah Berbasis Four Stage Method ( FSM ) yang Sustainable," J. Sist. Inf. Bisnis, vol. 9, no. 1, pp. 63-70, 2019.

[17] Pemerintah Kota Pekanbaru, Peraturan Walikota Pekanbaru No 56 Tahun 2019 Tentang Masterplan Pekanbaru Smart city, vol. 56. 2019.

[18] Kominfo, "Pekanbaru Kota Percontohan Di Indonesia," pekanbaru.go.id/, 2019. [Online]. Available: https://pekanbaru.go.id/p/news/pekanbaru-kota-percontohandi-indonesia-. [Accessed: 23-Dec-2020].
K. Aprianto, "Command Center, Wujud Pekanbaru Smart City Madani yang Dilirik Banyak Daerah," Cakaplah.com, 2018. [Online].

Available: https://www.cakaplah.com/berita/baca/17740/2018/02/28/com mand-center-wujud-pekanbaru-smart-city-madani-yangdilirik-banyak-daerah. [Accessed: 10-Oct-2020].

[20] Mal Pelayanan Publik Kota Pekanbaru, "SEKILAS TENTANG MPP KOTA PEKANBARU," mpp.pekanbaru.go.id. [Online]. Available: https://mpp.pekanbaru.go.id/\#About. [Accessed: 11Jan-2021].

[21] C. Yusainy, A. F. Chawa, and S. Kholifah, "Social Data Analytics sebagai Metode Alternatif dalam Riset Psikologi," Bul. Psikol., vol. 25, no. 2, pp. 67-75, 2017.

[22] E. Mailoa, "JURNAL RESTI Analisis Node dengan Centrality dan Follower Rank pada Twitter," J. RESTI, vol. 4, no. 5, pp. 937-942, 2020.

[23] H. Marisa and Andree, "Analisa Implementasi Smart City Madani Pemerintah Kota Pekanbaru dalam Upaya Sinergitas Program ASEAN Smart Cities Network (ASCN) 2030," J. Dipl. Int. Stud., vol. 2, no. 2, pp. 1-11, 2019.

[24] R. Haifulloh, E. P. Purnomo, and L. Salsabila, "Kehadiran Kartu Smart Madani dan Kartu Identitas Anak sebagai Program Pengembangan Smart City di Kota Pekanbaru," Gorontalo J. Gov. Polit. Stud., vol. 3, no. 1, p. 038, 2020.

25] F. L. Ramadhan, "Arahan Peningkatan Kesiapan Masyarakat Terhadap Rencana Pembangunan Kawasan Industri Di Kecamatan WongSorejo Kabupaten Banyuwangi,” 2015.

[26] A. Alamsyah, "The Role Of Social Network Analysis For Knowledge Management," J. Manaj. Indones., vol. 12, no. 4, pp. 209-214, 2013.

[27] P. H. Sanjani and A. Alamsyah, "Social Network Analysis pada Interaksi Sosial Twitter Mengenai Operator Telekomunikasi Seluler di Indonesia ( Studi pada Telkomsel dan Indosat Ooredoo )," SOSIOHUMANITAS, vol. XXI, no. 1, pp. 70-72, 2019.

[28] M. S. Setatama and D. Tricahyono, "Implementasi Social Network Analysis pada Penyebaran Country Branding 'Wonderful Indonesia,"' Indones. J. Comput., vol. 2, no. 2, p. 91, 2017.

[29] A. Feizi, S. Joo, V. Kwigizile, and J. Oh, "A pervasive framework toward sustainability and smart-growth: Assessing multifaceted transportation performance measures for smart cities," J. Transp. Heal., vol. 19, no. September, p. 100956, 2020.

C. E. W. Utomo and M. Hariadi, "Strategi Pembangunan Smart City dan Tantangannya bagi Masyarakat Kota," J. Strateg. dan Bisnis Vol.4, vol. 4, no. 2, pp. 159-176, 2016. 